\title{
Analysis of the Urduization Trend in Bapsi Sidhwa's Novels
}

\author{
Dr. Zahida Mansoor \\ National University of Computer and Emerging Sciences \\ Tayyaba Bint-e- Mehmood \\ National University of Computer and Emerging Sciences \\ Hira Zulfiqar \\ National University of Computer and Emerging Sciences
}

\begin{abstract}
The study investigated the trend of Urduization in Bapsi Sidhwa's novels; "The Crow Eaters" (1978) and "Water" (2006), with a focus on the use of Urduized nouns in the two novels. Urduization is the process of adding words from Urdu into the English language (Ali \& Ijaz, 2009). Pakistani literature in English began to make its presence felt both nationally and internationally in the 1970s. A significant feature of this literature was the language used by the Pakistani writers. The unrestrained use of local words and expressions, reflected a new confidence in the use of the English language by the Pakistani writers. Pakistani English (PE) as a non-native variety displayed the unique characteristics and features of cultural influence of the society. The borrowing of words from Urdu and the regional languages and incorporating them into structures and expressions signified the independent development of PE. A mixed method approach was employed and data was collected from a corpus of Urduized nouns, developed following the research pathway of Ahmed and Ali (2014), by creating contextualized categories of the nouns used in the two novels. Documentary evidence in the form of author interviews also formed part of the analysis. Findings showed that the extent of urduization remained the same with the author's use of urduized words in both her novels very nearly following similar trends. Most words were added to provide contextual clarity and create interest, demonstrating a consistency in her writing style over three decades.
\end{abstract}

Keywords: Urduization; Pakistani English; Cultural influence; Contextualized categories; Writing Style

DOI: $10.7176 / \mathrm{JLLL} / 79-01$

Publication date:May $31^{\text {st }} 2021$

\section{Introduction}

Writers instinctively convey exactly intended meanings in a communication. They quite often find linguistic resources of one language to be insufficient in communicating the desired expressions so they make use of other languages, particularly native, in their writings to convey accurate message in an appropriate context as well as to show the rich cultural impact of a society on a particular language (Mahmood \& Shah, 2011).

English is considered to play a vital role in 'globalization' of this world (Bottery, 2006). Being an international language, it is spoken in all parts of the world with approximately 430 million L2 users and 330 million L1 users (Crystal, 2003). These statistics are a clear indication of the fact that L2 speakers of English language are greater in number than those of L1 (Aravamudan, 2006). With the use of English in non-native contexts, it has evolved as a transplanted language due to socio-cultural differences among speakers, giving rise to the 'indigenization' process of the English language (Jadoon, 2017). According to Mufwene as cited by Sheeraz (2013), indigenization is a process in which innovations are adapted into a language due to the communicative habits of the non-native speakers of that language. Indigenization involves the processes of Americanization, Africanization and Urduization etc.

English enjoys a prestigious status in Pakistan. It has become the language of necessity as well as the language to display the social prestige and power (Manan S. A. Et al., 2017). This manifestation of power can be clearly observed in Pakistan where people tend to switch between Urdu and English to create special effects. Code switching and code-mixing is a common phenomenon used by Pakistani bilingual speakers. This variation in the English language causes the incorporation of Urdu lexical items in Pakistani English (PE), referred to "Urduization of English" with the Pakistani speakers and writers making a deliberate use of Urduized words in English even if those words have corresponding words in English. This induces the idea that sometimes it is necessary to use the words of native language in English writings for conveying the exact meanings of certain social, cultural or religious contexts (Ahmed \& Ali, 2014).

The writers in Pakistani diaspora have gained worldwide acclaim during the last three decades. As most works of fiction are written by the diaspora writers, the impact of Urduization has a noticeable place in their works. The development of English as a global language demands an extensive systematic study of its various varieties in the non-native contexts. Pakistani English (PE) is different from Standard British English (SBE) with 
incorporation of many Urdu words in the creative works of the diaspora writers.

Objectives of the study

The study explores the trend of Urduization in two books written by Bapsi Sidhwa, "The Crow Eaters" and "Water".

- To determine the contextualized categories of Urduized nouns used in Sidhwa's novels, "The Crow Eaters" and "Water"

- To explore the Urduization trend in Bapsi Sidhwa's novels, "The Crow Eaters" and "Water" over three decades.

Delimitations of the Study

The present study is limited to the use of Urduized nouns in two novels by Bapsi Sidhwa; the first novel, "The Crow Eaters", published in 1978 and "Water", published in 2006. The time gap between the two novels will be instrumental in exploring the extent of the Urduization trend in Sidhwa's novels.

\section{Literature Review}

With the advancement in the global communication, World witnessed a "Language Revolution" in twentieth century and English language gained the status of "the global lingua franca" (Schneider, 2007). But over the period of time, English language has experienced many adaptations in different parts of the world. These adaptations were carried out due to many reasons like having different social, historical, religious and cultural contexts. This resulted in many varieties of English, such as Postcolonial English, Global English, Australian English, Chinese English, South Asian English and so on. Linguists termed this process of heterogeneity as "Indigenization of English" (Baumgardner, 1993). The indigenization of English is a continuous process that is responsible for creating new linguistic codes by making unusual use of capital letters and implying regional words in English.

One of the postcolonial critics, Ashcroft et al (2002) termed this process of reshaping English as "appropriation" because of its encounters with different types of cultural experiences. Appropriation is a controlled and conscious process. It is also a strategic process because sometimes meanings in English are present for a specific word but the writer tends to use it in other language in order to get more 'appropriacy' and reader's attention. This makes both the terms look synonymous and interchangeable.

Kachru (1978) was the first to recognize and establish South Asian variety of English (SAE). He divided the process of arrival of SAE into three phases: i) When missionaries started to work in the early 17th century; ii) When English became the part of government policy after 1787; iii)When demand of English increased by people of South Asia in the beginning of 19th century. He believed that new linguistic innovations determined by the effect of cultural and commutative strategies must be kept in mind during the process indigenization of a language.

Works of Kachru show the elaborated study of South Asian English and he made extensive study on the use of hybridized structures which showed innovations in the South Asian varieties of English. This was a combination of one word of native language with an English language word, for instance, 'lathi charge, rickshaw-driver, child-lifter, Tonga-drivers, Police-wala, Tonga-wala' (Kachru. 1986). The studies undertaken by Kachru are of vital importance owing to the fact that a systematic analysis of the differences between the South Asian English and Standard British English have been they provided in them.

Muthiah (2009) explores the indigenization of the fictionalized English in works of South Asian writers that began with experiments with English lexis and syntax. This experimentation was responsible for giving rise to the indigenization process of the English language in South Asian literature, particularly in Pakistani English literature. Contemporary fictional works by Pakistani-American writers were characterized by this feature, termed earlier as 'Pakistanization of English', further explaining the Pakistani contemporary writers' use of strategies and techniques in the indigenous use of the English language.

English, spoken in Pakistan, is a non-native variety containing different lexical structures such as nouns from the native language i.e. Urdu. Mahboob (2003) described different phonological and grammatical aspects of Pakistani English, which are quite unlike the Standard British English. Kachru (1983) considers the South Asian English as the "link language for national and international purposes" while Rahman (1996) sees it as the "language of the domains of power - administration, judiciary, military, education, commerce".

Rahman (1990) has described the distinct patterns of lexical and semantic features in Pakistani English dividing Pakistani English into four sub-varieties. Variety A the "Anglicized English" is much closer to the Standard British English (SBE), while Variety B termed as "Acrloect English" is different from SBE in the morphological, phonological and syntactical domains. This variety is mostly used by the graduates from elitist English medium schools or by those who have exposure to SBE. He termed Variety C as "Mesolect English" spoken by the middle and upper middle class of society. The fourth sub-category is Variety D labelled "Basilect English" used by administrative officials of lower ranks such as clerks and typists. Rahman (1990) believed that these four sub-varieties of Pakistani English include Urduized words. These Urduized words register themselves 
in Pakistani English due to the religious, cultural and social influences on the language.

Tallat $(2002,2003)$ finds that meanings of some lexical items have been used in a different context in Pakistani English (PE) from that of SBE, claiming that PE is not a stable system and is ever changing because of the connections of PE with other languages, particularly with Urdu. Borrowed into Urdu, these loan words, when used by Pakistani bilingual English speakers, retain their Urduized meanings which are clearly distinguishable from SBE usage.

The inclusion of several Urdu words in English is a distinctive feature of Pakistani English and process is termed as Urduization. Baumgardner (1993) suggests that a large number of words borrowed from Urdu and other regional languages of Pakistan have been incorporated in Pakistani English. Such borrowing usually takes place from the spheres of ordinary lifestyle, religion, politics, arts and cultural norms. The Urduized words are frequently used in the English literature by writers of Pakistani English writers.

Indigenization of Pakistani English has taken place through borrowing from regional languages, word formation by combination of two words of different languages, such as 'Member-sazi', reduction at phrase level and grammatical changes in adjective, verb and noun complementation at sentence level (Baumgardner, 1993). This borrowing is done through transliteration, code-mixing and code-switching that brings out new linguistic innovations and catches the reader's interest. These linguistic improvisations are described as "Urduized English" (Manan, David, Dumanig \& Channa, 2017).

There is great influence of indigenous culture on the language used by Pakistani writers in their writings. Pakistani English, being a non-native and non-standard variety of English, has different words, structures and expressions embedded in it from other regional languages, especially Urdu. This signifies a unique and independent trend of Pakistani English (Ahmed \& Ali, 2014). As Baumgardner (1993) suggests:

"Urduized words in Pakistani English give it a linguistic and cultural identity and it is more evident in the large number of loan words from Urdu and the other regional languages which have made their way more common in Pakistani English. The influence of Urduization seems all pervasive in Pakistani English."

Writers, who are speakers of the Pakistani English, frequently use words from their native language in their writings even when those words have substitutes in English language (Mahmood \& Shah, 2011). Behzad (2007) in his study examined the use of Urduized words and the impact of Urduization upon in the Pakistani English Newspapers found innovative lexis use in Pakistani English newspapers.

For a better understanding of Pakistani English, identification and analysis of trend of Urduization is important. The present study is based on the novels of Bapsi Sidhwa and explores the trend of Urduized nouns used in different contextualized categories in two of her novels, "The Crow Eaters" and "Water", written twentyeight years apart.

\section{Methodology}

A mixed method approach is employed in the study. A corpus was developed by collecting the Urduized Nouns used in the two novels "The Crow Eaters" and "Water" written by Bapsi Sidhwa.

\section{Sample}

The sample consisted of the novels "The Crow Eaters" and "Water", and author interviews. Systematic Sampling technique was used for the sample selection as the novels were chosen in their chronological order written twenty-eight years apart; "The Crow Eaters" written in 1978 and "Water" was published in 2006. The author interviews were used to gain insight about Sidhwa's approach towards Urduization in her writings in English.

\section{Data Collection}

The method of data collection was document review by further analysis through content analysis. The data of the research was Urduized nouns used in the two novels. The Urduized nouns in the lexical category of nouns were identified, collected and categorized to check the trend of Urduization in Bapsi Sidhwa's novels over time. The data also checked and recorded the frequency of Urduized nouns using the software "AntConc (Version 3.5.0)" along with Kindle Reader (Version 1.21.0). This process was informed by the works of Baumgardener (1993), and Ahmed and Ali (2014).

A table showed division of Urduized Nouns from the two novels of Bapsi Sidhwa; "The Crow Eaters" and "Water", in daily life categories as well as the occurrences of those urduized nouns in respective novels.

\section{Data Analysis}

Content analysis based on the framework used by Ahmad and Ali (2014) in their study was used to analyze the data. The novels were meticulously read and all urduized nouns were extracted and categorized. The softwares 'AntConc' and Kindle Reader were used to find the frequency as well as the number of occurrences of urduized nouns in the two novels. For the quantitative analysis, the urduized nouns were grouped into eight distinct categories; religion; food and drink; relationships; culture; clothing; plurals; and miscellaneous. The 
contextualized usage has been supported through numerical data in terms of frequency of occurrences of Urduized nouns. All frequencies were obtained with the aid of "AntConc" and "Kindle Reader", to ensure the objectivity of the data and reliability of the results.

\section{Urduized Nouns Comparison}

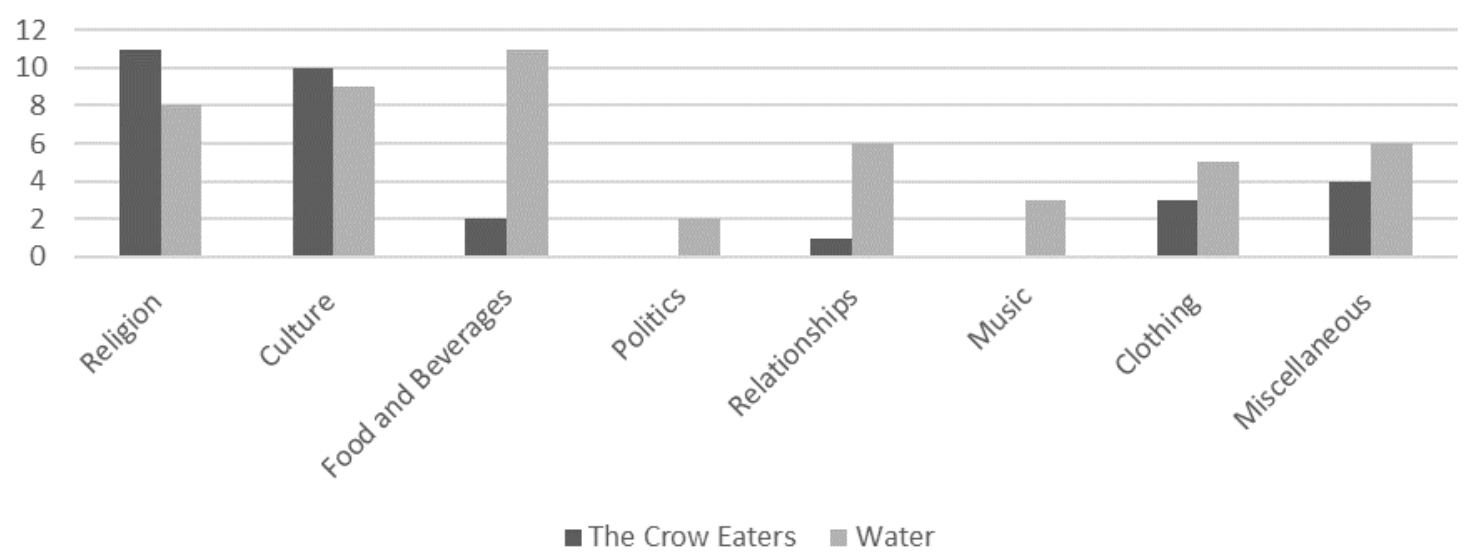

Figure 1. Urduized Nouns comparison in "The Crow Eaters" and "Water"

Figure 1 shows a comparison of urduized nouns, found in "The Crow Eaters" and "Water". The frequencies of their occurrences in both the novels and corresponding categories have also been described further. These categories were assigned domains like religious, culture, political, clothing, music and miscellaneous (Ahmad \& Ali, 2014).

Religion

Eleven nouns linked with religious beliefs in the novel "The Crow Eaters" signify concepts related to Islam, Zoroastrianism and Hinduism. On the other hand in "Water", the occurrence of such nouns fell to eight, associated specifically with Hinduism. The frequencies show a decrease in the use of religiously disposed words over time. This may be due to one religion being given emphasis in the novel "Water" while "The Crow Eaters" simultaneous discussion of three religions increased the frequency of such words.

Culture

The category of urduized nouns reflecting culture in the novel "The Crow Eaters" contains ten urduized nouns associated with the Muslim and Hindu culture. While, In 'Water', nine urduized nouns from the cultural category show a minor decrease. The nouns are mostly related to one culture, while "The Crow Eaters" portrayed two cultures, with more urduized nouns.

Food and Beverages

"The Crow Eaters" contained two urduized nouns in the category of nouns related to food. However, in "Water" an increase in the use of the food category nouns is seen with, eleven urduized nouns. The findings indicate the use of more urduized nouns in the food category in Sidhwa's recent novel.

Politics

Urduized nouns related to political usage and connotations show minimal coverage in both the novels. "The Crow Eaters" did not contain any political Urduized nouns, while in "Water", two nouns made their appearance in the novel within this category. Suggesting the element of politics in the setting of "Water".

\section{Relationships}

The category based on nouns referring to relationships shows minimal use in "The Crow Eaters", while multiple occurrences of nouns signifying relationships are evident in "Water". "The Crow Eaters" focus on the overall social settings pertaining to different religions and cultures while in "Water", the shift in the focus to a single setting, suggests a deeper understanding of social values and relationships within the Hindu culture.

Music

The nouns categorized under this category refer to musical terminology or instruments. The novel "The Crow Eaters" had no nouns related to the category of music while in "Water", three Urduized Nouns related to music category are included. Apart from the storyline and the setting differences in both the novels, the writer has used music related nouns in "Water" to offer a closer look at the cultural importance and interpretation of music in Hinduism.

Clothing

This category contains all the Urduized nouns referring to different items related to clothing. In the novel "The Crow Eaters", the three urduized nouns were used, whereas in "Water", the number increased to five, suggesting a more detailed explanation of attire. 


\section{Miscellaneous}

In the miscellaneous category the number of Urduized nouns For "The Crow Eaters" included names of trees, tobacco and household items. For the novel "Water", the nouns referred to categories of places, furniture and abusive words. There were four nouns found under such miscellaneous categories in "The Crow Eaters" while six nouns were present under the similar categories in "Water".

Analysis of Sidhwa's Interviews

The native language of Sidhwa is Gujrati; one of the Indian languages that give its users the liberty to play around with the language having diverse choice of words. Gujrati and Urdu were her first and second languages respectively, however according to Sidhwa felt her reading and writing was the best in English. In an interview, Sidhwa expressed the socio-historical reasons that made her write in English language and her choice of words from other languages integrated into her English writings (Jussawalaa \& Dasenbrock, 1992).

Sidhwa, herself, has also acknowledged that her English writings were often marked with words taken from Gujrati and Urdu languages and that her writing style is influenced by the way she speaks. She named her style as "salad of languages" that includes Urdu, Gujrati as well as English (Jussawalla and Dasenbrock, 1992).

While answering the most commonly asked question about her choice of language as English for her writings, Sidhwa (2012) narrated that English has always enjoyed an elite status in sub-continent. Although there were no more white people in sub-continent after the partition of 1947 yet English maintained its prestige. It was still considered to be the language of privileged and language of power and had been a 'major link language of the world' (Sidhwa, 2012). There were many other languages spoken in the sub-continent but English language held its place. However, English has experienced a great metamorphosis in the sub-continent and has been indigenized to a great extent with inclusion of words from other languages. Sidhwa (2012) claims that "We, the ex-colonized, have subjugated their language, and molded it to our requirements." Suggesting that manipulation of the English language in her writings has given it a new shape and dimension.

Sidhwa confessed in interview with Jussawalla and Dasenbrock (1992) that she had used the indigenization techniques extensively in her novels, indicating "I am free to take what I wish from the riches each offers: the earthy gusto of Punjabi, the poetry and delicacy of Urdu." Claiming that these techniques gave a rhythmic flow to her narrations bringing spontaneity in her work that connects to the everyday conversation style of the subcontinent. She believes that to present the true cultural essence one has to manipulate the language with the words or idioms from other languages. But along with this she also mentioned the fact that the inclusion of the words from Urdu was more of an unconscious action that added a cultural flavor to her writings. She feels obligated to show snapshots of the Pakistani culture in her writings for those who are not familiar with it (Sidhwa, 1993).

Apart from the depiction of culture, Sidhwa's modernist or post-modernist style contains a verbal jugglery (Nandhini \& Madhan, 2017). "I think you just juggle for the best meaning, somehow. And certain words are so much more expressive in another language." Suggesting that words from other languages have been incorporated into her writings to convey not just the meanings but the context as well. In addition Sidhwa commented that some Urdu words carried the tonal quality completely understandable in English as well. For example the word badmash contains 'bad' in it that means not good in English, so one who does not know Urdu can also guess its meaning to some extent. However with the use of these words she has only tried to demonstrate their "status and function", not just to fill up the place (Sidhwa, 2012). Like she recounts that 'cart' can be used for rehra but 'pants' would not be appropriate to use in place of dhoti (which is more of a skirt). She has used the Urduization approach in order to communicate better with her readers.

She also has the opinion that sometimes she adds the words of Urdu to intensify her writings and to create certain effects. She recounts that this case is not just confined to her being the foreign language writer but some native British English writers also practice the same while writing about India to build specific atmosphere.

\section{Findings}

The presence of Urduized nouns in both the novels suggests that Pakistani English is indeed in a process of Urduization (Baumgardner, 1993). In addition, the findings suggest that the trend of Urduized nouns in both novels is similar, occurring frequently in both the novels.

The next stage of analysis involved the division of Urduized nouns into contextualized categories which was in accordance with Ahmad and Ali's work (2014). It was observed through the classification of categories that the number of Urduized nouns belonging to individual categories for both the novels was not the same. For instance, for the novel "The Crow Eaters", the nouns belonging to religious and culture specific categories were more in number as compared to the Urduized nouns in "Water" for similar categories. Similarly, the categories of relations, eatables and clothing had less Urduized nouns in case of "The Crow Eaters" as compared to "Water".

Moreover, two new categories for the categorization of Urduized nouns emerged for the novel "Water", that were music and political nouns based categories. These categories did not exist for "The Crow Eaters" which 
suggests a context that is different for "Water". In case of "The Crow Eaters", the setting of the novel is purely sociocultural reflecting more about the culture and living style of South Asia as depicted by the Urduized nouns. Although "Water" shares a similar social and cultural context with "The Crow Eaters", it possesses a storyline of its own that also encompasses a political setting. Due to this, two nouns pertaining to political category were found in "Water". Similarly, "Water" touches upon the theme of music as three Urduized nouns have been used under this category. The use of such nouns indicates Sidhwa's ability to choose words from Urdu in order to present a clear notion of the culture she is writing about.

\section{Conclusion}

The findings suggest that Sidhwa maintained a comparable trend of Urduization in both her novels over the timespan of 28 years. Although, both her novels exhibit a similar trend of Urduized nouns in terms of occurrences and frequencies, however, it is their use and contexts that make them different from each other. Admittedly, alternative in Standard British English are available for many of the Urduized nouns (Ahmad \& Ali, 2014), the writer has used the Urduized nouns to capture the essence of the South Asian contexts in her novels. Even among both the novels, the contexts of religion, culture and politics are not identical and the timeline for both the novels also contains a gap of almost three decades. Suggesting that Sidhwa has managed to maintain her particular style of writing in order to distinguish between the Pakistani English and Standard British English.

Her manipulation of specific language reflects a touch of her own culture in it. She has carried out innovations in English language in her works of fiction showing a strong impact of culture in her writings. Her interviews have described the fact that she has done this manipulation of language in order to give a more South Asian color to her writings (Sidhwa, 2012). She uses Urduized words in her novels in order to express the context in the manner in which it exists.

\section{Future Research}

This research dealt with examination of trend of Urduization for the first and latest novel of Bapsi Sidhwa. Similar research can be conducted for other Pakistani authors to examine the extent to which Pakistani English is being urduized by them. Moreover, this research focused on lexical category of nouns; further research can evaluate if any other lexical categories are urduized in Pakistani English. Furthermore, the primary focus of this research was to identify Urdu nouns used throughout both the novels of Bapsi Sidhwa. Parallel researches can identify words in the regional languages of Pakistan being used by other Pakistani authors in their writings.

\section{References}

Ahmad, S. (2011). Concord with Collective Noun in Pakistani English. MPhil Thesis Government College University Faisalabad.

Ahmad, S. \& Ali S. (2014). Impact of Urduized English on Pakistani English Fiction. University of the Punjab, Lahore.

Ali, A. R., \& Ijaz, M. (2009). English to Urdu Transliteration System. Proceedings of Language and Technology, $15-23$.

Anwar, B. (2007). Urdu-English Code Switching: The Use of Urdu Phrases and Clauses in Pakistani

Aravamudan, S. (2006). Duru English: South Asian religion in a cosmopolitian language.

New Jersey: Princeton University Press.

Baumgardner, R. J. (1993). The English Language in Pakistan. Karachi: Oxford University Press.

Baumgardner, R. J., Kennedy, A. E. H., \& Shamim, F. (1993). The Urduization of English in Pakistan. In R. J. Baumgardner (Ed.), The English Language in Pakistan. Karachi: Oxford University Press.

Bottery, M. (2000) Education, Policy and Ethics. London: Continuum.

Crystal, D. (2003) English as a Global Language. 2nd edition. Cambridge: Cambridge University Press.

Jadoon N. K. (2017) Pakistanization of English in Kamila Shamsie'sKartography. International Journal of English Language and Linguistics Research Vol.5, No.4, pp. 1-17, August 2017, Published by European Centre for Research Training and Development UK

Jussawalaa, F., Dasenbrock, W. D. (1992). Interviews with Writers of the Post-Colonial World. University Press of Mississippi

Kachru, B.B. (1983). Kachru, B.B. (1982). The Other Tongue. Oxford: Pergamum.

Kachru. B. B. (1983). The Indigenization of English: The English Language in India. Delhi: Oxford University Press

Kachru, B. B., Yamuna, \&Nelson, C. (2006). (Eds.). The Handbook of Varieties of English. Oxford: Blackwell

Manan S. A. Et al. (2017) The globalization of English in the Pakistan linguistic landscape, World Englishes, 2017, John Wiley \& Sons Ltd

Mehmood, A. (2009). Corpus-Analysis of Pakistani English. PhD thesis. The Department of English Literature, BahayudinZakaria University Multan 
Mehmood, R. (2009). Lexico-Grammatical Study of Noun Phrase in Zakaria Pakistani English. PhD thesis. The Department of English Literature Bahayudin University Multan

Muthiah, K. (2009). Fictionalized Indian English Speech and the Representations of Ideology in Indian Novels in English. Phd thesis, University of North Texas.

Nandhini, P., Madhan, P. (2017) A thematic study on the select novels of BapsiSidhwa. Shodhganga : a reservoir of Indian theses

Rahman, T. (1990). Pakistani English. Islamabad: National Institute of Pakistan studies.

Schneider, E. W. (2007). Postcolonial English: Varieties around the world. New York: Cambridge University Press.

Sheeraz M. (2013) Samosa-Quoting English: Formula and Favaid of the Indigenized Language Of PakistaniAmerican Fiction

Sidhwa, B (2012). Writing in English. A Subcontinental Novelist's Perspective Le Simplegadi, 2012, X, 10: 1128. - ISSN 1824-5226

Sidhwa, B. (1993). New English creative writing: A Pakistani writer's perspective. In Baumgardner, R. J. (Ed.). The English Language in Pakistan. 212-220. Karachi: Oxford University Press

Talaat, M. (2002). Form and Functions of English in Pakistan. PhD Thesis: The Department of English literature Bahayudin Zakaria University Multan. 